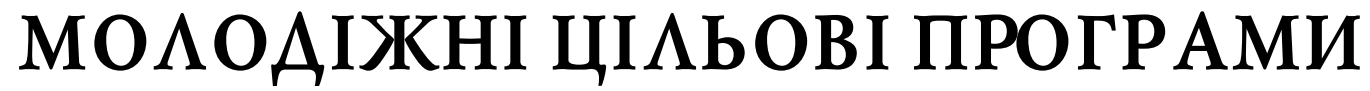 ЯК АІЕВИЙ ІНСТРУМЕНТ РЕААІЗАЦІЇ

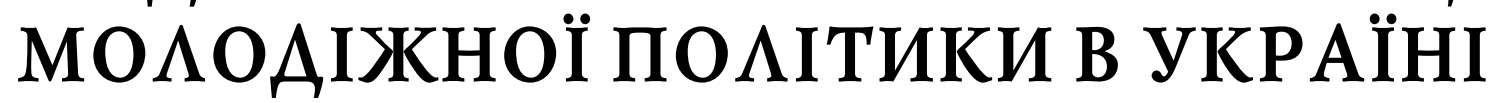

\author{
S. Grynchyshyn, \\ graduate student of the Ukrainian State Employment Service Training Institute
}

\author{
YOUTH TARGET PROGRAMS AS A DEVELOPMENT TOOL FOR THE IMPLEMENTATION \\ OF THE YOUTH POLICY IN UKRAINE
}

У даній статті досліджено молодіжні цільові програми як дієвий інструмент реалізації молодіжної політики України. 3 цією метою виокремлено п'ять основних періодів розвитку молодіжної політики в Україні. Розглянуто основні положення молодіжної політики на кожному етапі та виявлено характерні недоліки. Проаналізовано динаміку загального обсягу фінансування реалізації програми "Молодь України" на 2016-2020 роки. 3'ясовано, що для подальшого розвитку та реалізації молодіжних цільових програм необхідно зробити такі кроки посилити політику, спрямовану на забезпечення молоді необхідними умовами для їх фізичного та морального розвитку; посилити співпрацю різних інституцій у напрямі більш ефективної реалізації молодіжних цільових програм; забезпечити цільову спрямованість програм розвитку молоді; розробити сучасну методологію та інноваційний інструментарій для реалізації молодіжних цільових програм; популяризувати здоровий спосіб життя якєдино правильний в сучасних умовах урбанізації та інформатизації; впровадити новітні стандарти якості в сфері охорони здоров'я молодого покоління; популяризувати відвідування закладів спортивно-виховного спрямування; створити осередки розвитку неформальної освіти з метою професійної орієнтації молоді; запровадити партисипативні технології для активного залучення молоді до процесу державотворення; забезпечити необхідні умови для розвитку молодіжних організацій та центрів розвитку; активізувати інвестиційну діяльність у сфері реалізації молодіжної політики; забезпечити механізми для розвитку та раціонального використання творчого потенціалу молоді; створити необхідні умови для залучення молоді до участі в міжнародних проектах; забезпечити підвищення інформаційно-комунікаційної компетентності молоді; створити умови для залучення дослідницьких установ до моніторингу та коригування молодіжних цільових програм. При цьому встановлено, що основними проблем, які стримують реалізацію молодіжних цільових програм в Україні належить: недосконале правове регулювання, недостатня наукова обгрунтованість процесу реалізації молодіжних цільових програм; відсутність ефективної взаємодії між центральними та місцевими органами виконавчої влади, а також різноманітними громадськими об'єднаннями; відсутність чітких прав та обов'язків, які лежать перед молоддю та іншими суб'єктами реалізації цільових молодіжних програм. Разом із тим, доведено, що вирішенню вищенаведених проблем сприятимуть вчасно створені організаційні, соціально-економічні, політико-правові умови щодо соціального становлення та розвитку молоді.

The statistics of the young people of the youth programs of the youth policy of Ukraine. I use the principle of using the main periodes of the development of youth policies in Ukraine. Rozgulanno fundamentally laid youth policies on the skin etapi that hive characteristic features shortcomings. Analyzed the dynamic of the implementation of the "Young Ukraine" program for 2016-2020. It has been done, for the development that real development of the young main programs is necessary for the sake of the young people, to enforce the policy, which is hidden in the minds of young people with the minds for their physical and moral development; make it easier for other institutions for direct use of effective real-estate youth programs; protect the program development of the youth; develop the methodology and innovation tools 
for real-world youth programs; promote health in life, as it is right in the minds of urbanization and informatization; enter new standard standards in the sphere of protection of the young generation; to popularize the founding of sports and cyclical fitness; the focus of the development of informal learning by means of professional oriental youth; prohibit the participation of technology for active young people before the process of creation; protect the need for development of young organizations and centers of development; activize investment activities in the realm of youth politics; protect the mechanism for development and development of a creative creative potential for young people; prerequisites for getting young people to take part in international projects; protect your personal information and communication and youth competence; limit drain for the dosninnitskih install before monitoring that koriguvannya youthful programs. At the same time, it was established that the main problems that hinder the implementation of youth target programs in Ukraine are: imperfect legal regulation, insufficient scientific validity of the implementation of youth target programs; lack of effective interaction between central and local executive authorities, as well as various public associations; the lack of clear rights and obligations that lie with the youth and other actors in the implementation of targeted youth programs. At the same time, it has been proved that the organizational, socio-economic, political and legal conditions for the social formation and development of youth will be facilitated by the timely establishment of the above-mentioned problems.

Ключові слова: молодь, молодіжна політика, державні програми, цільові програми, молодіжні цільові програми.

Key words: young people, young people policies, state programs, programs, youth programs.



ЗАГААЬНОМУ ВИГАЯАІ ТА ÏÏ ЗВ'ЯЗЗК I3

ВАЖАИВИМИ НАУКОВИМИ ЧИ

\section{ПРАКТИЧНИМИ ЗАВААННЯМИ}

Для сучасного етапу розвитку вітчизняного суспільства характерним $є$ розвиток процесів демократизації та інтеграції України у світову спільноту. Такий вектор розвитку зумовлює необхідність нашої держави перейти від пасивного стану до здійснення практичних кроків у відповідності з численними викликами сучасності. Молодь, як найбільш схильна до інновацій соціальна група, здатна брати участь у подібному переходу значно активніше, ніж представники старшого покоління. Для молодих людей характерними рисами мобільність та енергійність, готовність до розвитку власного творчого потенціалу. Саме ці якості можуть бути ефективно використані у процесі державотворення та суспільнополітичних змін у країні.

\section{АНА $\Lambda$ I3 ОСТАНHIX АОС $\Lambda$ IАЖЕНЬ I} ПУБАІКАЦІЙ, В ЯКИХ ЗАПОЧАТКОВАНО РОЗВ 'ЯЗАННЯ ААНОЇ ПРОБ АЕМИ I НА ЯКІ СПИРАЕТЬСЯ АВТОР, ВИАІ ЕННЯ НЕ ВИРІШЕНИХ РАНІШЕ ЧАСТИН ЗАГААЬНОЇ ПРОБАЕМИ, КОТРИМ

\section{ПРИСВЯЧУЄТЬСЯ ОЗНАЧЕНА СТАТТЯ}

Дослідженню даного питання присвятили свою увагу такі науковці: Є. Бородін, Т. Тарасенко, І. Хозрякова, А. Фартушна, В. Мунтян, І. Кульчій, Т. Лебедин та ін.

\section{META CTATTI}

Метою статті $є$ дослідження молодіжних цільових програм як дієвого інструменту реалізації молодіжної політики України.

\section{ВИК ААА ОСНОВНОГО МАТЕРІААУ АОС АІАЖЕННЯ 3 ПОВНИМ ОБГРУНТУВАННЯМ ОТРИМАНИХ НАУКОВИХ РЕЗУ $\triangle$ ЬТАТІВ}

XXI ст. позначене радикальними змінами способу життя та фрормату діяльності світового суспіль- ства. Невпинний розвиток технічного прогресу дає змогу відкриття нових перспектив для людей, а також створення нових можливостей для розвитку різних соціальних груп. Крім того, спостерігається підвищення мобільності кожного окремого індивіда - як просторової, так і соціальної. При цьому найбільш перспективною соціальною групою у даному контексті вбачається саме молодь, яка завдяки вказаних якостям здатна активно впливати на розвиток суспільно-політичного життя України. Сукупність вказаних чинників підтверджують актуальність дослідження питань формування та реалізації молодіжних цільових програм.

Євроінтеграційний вектор розвитку країни стає можливим завдяки здатності молоді імплементувати європейські цінності в українські реалії і робити відповідні зміни на місцевому та державному рівнях. Розвиток молодих українців можливий у разі впровадження державою повноцінної та всебічної молодіжної політики, що потребує відповідного фрінансування. Нині в Україні діє державна цільова соціальна програма "Молодь України", однак низка фракторів робить дію цієї програми неефективною, частково нівелюючи потенціал молоді країни [5].

Найбільш пріоритетними завданнями, що стоять перед органами влади є активний розвиток економіки, розбудова відкритого суспільства, інтеграція України у світову спільноту. Аналіз досвіду формування та реалізації державної молодіжної політики в Україні дає змогу виокремити п'ять основних періодів:

1991-1996 рр. - період виокремлення та зміцнення "молодіжного сектору" державного управління та публічної політики;

1996-2004 рр. - період розширення молодіжної складової соціально-гуманітарної політики та поступового її входження до інтегрованої державної політики стосовно сім'ї, дітей та молоді в Україні;

2005-2014 рр. - період вдосконалення державного управління у сфері державної молодіжної політики та пошуку інноваційних підходів до її рефрормування. 
2015 р. - період схвалення Концепції молодіжної політики на 2015 рік; відродження національно-патріотичного виховання молоді (Постанова Верховної Ради України № 26-УІІІ прийнята 11 грудня 2014 року "Про Програму діяльності Кабінету Міністрів України") [1];

2016-2020 рр. - зростання рівня участі молоді у суспільно-політичному житті держави і формуванні політики з питань, що впливають на її життя, розвиток та вирішення нагальних проблем [2].

Для реалізації молодіжної політики органами державної влади розроблюються молодіжні програми у напрямах розвитку та становлення молоді, громадянського суспільства, забезпечення молоді роботою та житлом тощо. Серед найбільш вагомих програм щодо реалізації молодіжної політики в Україні стала державна програма "Молодь України", що носила різні назви у різні періоди її існування [5].

Наприкінці 1990-х - на початку 2000-х рр. почалося реформування центральних органів виконавчої влади з питань молодіжної політики. Так, з 1999 р. по 2013 р. подібні рішення приймалися вісім разів. Таким чином, шляхом створення, ліквідації та реорганізації Комітетів і Міністерств в галузі молодіжної політики, з липня 2013 року діє Міністерство молоді та спорту України [4].

Загальнодержавні молодіжні цільові програми $є$ важливими завдяки концептуальним положенням та нормам законодавства, які дають змогу перетворити науково-теоретичні напрацювання у конкретні кроки щодо розвитку молодого покоління. Наша держава потребувала певного проміжку часу для напрацювання основних орієнтирів розвитку молодіжної політики, оскільки, як відомо, до кінця 90-х років комплексний документ у зазначеній сорері був відсутній.

Вперше документ зі статусом загальнодержавної молодіжної програми "Молодь України" (Комплексні заходи Кабінету Міністрів України щодо реалізації державної молодіжної політики в Україні) було затверджено постановою Кабінету Міністрів України від 20 березня 1998 р. [3].

Метою Комплексних заходів було проведення цілісної молодіжної політики, визначеної Декларацією "Про загальні засади державної молодіжної політики в Україні" та Законом України "Про сприяння соціальному становленню та розвитку молоді в Україні", іншими законодавчими та нормативними актами щодо створення сприятливих умов для життєвого самовизначення та самореалізації молодих громадян, підтримки їх інноваційної діяльності, розвитку молодіжних громадських організацій, сприяння роботі у розв'язанні проблем молоді [4].

Комплексні заходи програми "Молодь України" визначили загальні принципи, головні напрями та основний зміст підтримки і захисту молоді, забезпечення духовно-культурного та фрізичного її розвитку, формування морально-правової культури, становлення молодої сім'ї, профрілактики негативних явищ у молодіжному середовищі, державної підтримки розвитку молодіжного підприємництва тощо [3].

Наступний результативний досвід молодіжного програмотворення реалізувався у вигляді "Загальнодержавної програми підтримки молоді на 20042008 роки", затвердженої Законом України від 18 лис- топада 2003 року. Основними завданнями Програми були: сприяння ініціативі та активності молоді в усіх сорерах життєдіяльності суспільства, розширення її участі у формуванні та реалізації державної політики щодо розв'язання соціальних проблем молоді; поліпшення координації зусиль органів державної влади та громадських організацій у сорері реалізації державної молодіжної політики; підвищення ефективності державної молодіжної політики на регіональному рівні; зміцнення матеріально-технічного та фрінансового забезпечення установ, закладів, громадських організацій, що працюють $з$ дітьми та молоддю; підтримка молодіжних і дитячих громадських організацій та їх спілок у реалізації програм, спрямованих на вирішення проблем молоді [6].

Державну цільову соціальну програму "Молодь України" на 2009-2015 роки Кабінет Міністрів України затвердив постановою від 28 січня 2009 р. [7]. Такий крок повернув практику ухвалення урядових молодіжних програм, яка існувала в Україні до 2004 р. На наш погляд, статус закону надав би програмі "Молодь України" більшої вагомості, що перенеслося б і на ставленні влади та суспільства до молодіжної політики загалом [4].

Метою Державної цільової соціальної програми "Молодь України" на 2009-2015 рр. було визначено створення системи всебічної підтримки громадянської активності молоді, спрямованої на самовизначення і самореалізацію, формування необхідних для цього правових, гуманітарних та економічних передумов, надання соціальних гарантій [3].

Значним недоліком Програми на 2009-2015 рр. стала відсутність завдання щодо забезпечення молоді житлом, що нині є проблемним та невирішеним у нашій державі. Розробники Програми на 2016-2020 рр. включили його до переліку завдань, однак заходи, передбачені його в рамках, зводяться лише до інформаційної, пропагандистської, консультативної роботи. Це ставить під сумнів доцільність і, відповідно, ефективність освоєних бюджетних коштів під час проведення даних заходів із вирішення проблеми забезпечення молоді житлом [5].

18 лютого 2016 року ухвалено програму "Молодь України" на 2016-2020 роки. Метою Програми є створення сприятливих умов для розвитку і самореалізації української молоді, формування її громадянської позиції та національно-патріотичної свідомості. Реалізація попередніх програм дала певні позитивні результати. Напрацьовано нові механізми підтримки молоді, що знайшли своє відображення у дорожній карті реформування молодіжної сорери. Проте існує ще багато проблем, пов'язаних з достатньо низьким рівнем економічної та громадської активності молоді. Так, за результатами соціологічного дослідження у 2015 році попри існування достатньої кількості молодіжних громадських організацій тільки 2 відсотки молоді є членами таких організацій та 6 відсотків молоді відвідують організовані ними заходи. Залишається доволі низькою участь молоді у суспільно-політичному житті держави і формуванні політики з питань, що впливають на її життя, розвиток та вирішення нагальних проблем. Тільки 5 відсотків молодих людей брали участь 
Таблиця 1. Прогнозні обсяги та джерела фінансування на 2016-2020 роки

\begin{tabular}{|l|l|l|l|l|l|l|}
\hline \multirow{2}{*}{ Джерела фінансування } & \multirow{2}{*}{$\begin{array}{c}\text { Обсяг } \\
\text { фінансування, }\end{array}$} & \multicolumn{5}{|c|}{ У тому числі за роками } \\
\cline { 5 - 8 } & тис. гривень & 2016 & 2017 & 2018 & 2019 & 2020 \\
\hline Державний бюджет & 186328,8 & 8824,8 & 15145,5 & 53728,5 & 52362,9 & 56267,1 \\
\hline Місцеві бюджети & 277882,58 & 47363,92 & 49201,22 & 54642,58 & 60186,85 & 66488,01 \\
\hline Інші джерела & 13613,31 & 2323,8 & 2289,51 & 2750 & 3000 & 3250 \\
\hline Усього & 477824,69 & 58512,52 & 66636,23 & 111121,08 & 115549,75 & 126005,11 \\
\hline
\end{tabular}

Джерело: [2].

в обговоренні законопроектів на державному або місцевому рівні [2].

Відповідальність за виконання даної програми покладено на: Міністерство молоді та спорту, Міністерство освіти і науки, Міністерство внутрішніх справ, Міністерство оборони, Міністерство економічного розвитку, Міністерство соціальної політики, Міністерство культури, Міністерство регіонального розвитку, Державну службу України з надзвичайних ситуацій, Національну академію наук, Національну академію педагогічних наук, Національну академію медичних наук, обласні та Київську міську державну адміністрацію.

Державою було заплановано виділення спеціальних коштів на реалізацію даної програми з державного та місцевого бюджетів. У таблиці 1 наведено прогнозні обсяги та джерела фрінансування на 2016-2020 роки.

Динаміка загального обсягу фінансування реалізації програми "Молодь України" на 2016-2020 роки наведена на рисунку 1.

Таким чином, можемо спостерігати, що обсяг фрінансування реалізації програми "Молодь України" має тенденцію до зростання. Так, якщо у 2016 році було виділено 58512,52 тис. грн, то у 2020 році заплановано виділити кошти у сумі 126005,11 тис. грн. При цьому 66488,01 тис. грн буде направлено з місцевих бюджетів, a 56267,1 тис. грн з державного бюджету.

Виконання Програми дасть змогу [2]:

- збільшити щороку на 10 відсотків кількість молоді, залученої до програм та заходів, спрямованих на національно-патріотичне виховання та підвищення рівня громадянської свідомості молоді;

- збільшити щороку на 4 відсотки чисельність молоді, залученої до популяризації та утвердження здорового і безпечного способу життя та культури здоров'я;

- створити цілісну систему неформальної освіти молоді;



Рис. 1. Динаміка загального обсягу фінансування реалізації програми "Молодь України" на 2016-2020 роки

Джерело: [2].
- збільшити щороку на 50 осіб підготовку працівників, які працюють з молоддю, із залученням державних службовців молодіжної сфери і представників молодіжних громадських організацій та забезпечити видачу зазначеним працівникам відповідних сертифікатів;

- забезпечити розвиток молодіжного підприємництва шляхом удосконалення існуючої нормативно-правової бази та систематизації преференцій для молодих підприємців, фрормування підприємницьких навичок молоді;

- забезпечити надання підтримки молоді у працевлаштуванні та сприяти створенню для неї нових робочих місць;

— підвищити рівень самоорганізації і самоврядування інститутів громадянського суспільства та їх осередків;

- забезпечити залучення молоді до волонтерства як фрорми суспільно значущої діяльності вторинної зайнятості;

- знизити рівень правопорушень серед молоді до 2020 року на 20 відсотків, активізувавши правову освіту та участь молоді у суспільно значущій громадській діяльності;

- забезпечити ефективне виконання державних i регіональних програм з метою забезпечення молоді житлом, насамперед осіб з особливими потребами, молодих сімей, що мають у своєму складі учасників бойових дій, інвалідів війни, а також молодих сімей, один із членів якої загинув (пропав безвісти) або помер внаслідок поранення, контузії чи каліцтва, одержаних під час захисту Батьківщини;

- забезпечити інтеграцію української молоді в європейські та світові молодіжні структури;

- збільшити щороку на 5 відсотків чисельність молоді, що бере участь у реалізації проектів ЄС та інших іноземних держав, зокрема програми "Erasmus +".

Як показав аналіз, розробники програми користувалися оптимістичним сценарієм економічного розвитку країни та не врахували умови невизначеності внаслідок затягнутої економічної та політичної кризи. Наступним недоліком, що стосується цільових програм держави та конкретно цієї в цьому разі, $є$ спрямованість на кількісний результат. У своїх звітах органи влади оперують обсягом коштів та кількістю залученої до заходів молоді. Однак при цьому нівелюється поняття ефективності заходів на основі корисності, економічного ефекту в майбутньому (що особливо стосується завдання 3 працевлаштування молоді) [5]. 
Для подальшого розвитку та реалізації молодіжних цільових програм необхідно зробити наступні кроки:

- посилити політику, спрямовану на забезпечення молоді необхідними умовами для їх фрізичного та морального розвитку;

- посилити співпрацю різних інституцій у напрямі більш ефективної реалізації молодіжних цільових програм;

- забезпечити цільову спрямованість програм розвитку молоді;

- розробити сучасну методологію та інноваційний інструментарій для реалізації молодіжних цільових програм;

- популяризувати здоровий спосіб життя, як єдино правильний в сучасних умовах урбанізації та інфооматизації;

- впровадити новітні стандарти якості в сорері охорони здоров'я молодого покоління;

- популяризувати відвідування закладів спортивно-виховного спрямування;

- створити осередки розвитку неформальної освіти з метою професійної орієнтації молоді;

- запровадити партисипативні технології для активного залучення молоді до процесу державотворення;

- забезпечити необхідні умови для розвитку молодіжних організацій та центрів розвитку;

- активізувати інвестиційну діяльність у сорері реалізації молодіжної політики;

- забезпечити механізми для розвитку та раціонального використання творчого потенціалу молоді;

- створити необхідні умови для залучення молоді до участі в міжнародних проектах;

- забезпечити підвищення інформаційно-комунікаційної компетентності молоді;

- створити умови для залучення дослідницьких установ до моніторингу та коригування молодіжних цільових програм.

\section{ВИСНОВКИ 3 ПРОВЕАЕНОГО АОСАІАЖЕННЯ І ПЕРСПЕКТИВИ ПОАААЬШИХ РОЗВІАОК У ЦЬОМУ НАПРЯМІ}

Підсумовуючи усе вищесказане, можемо зробити висновок, що до основних проблем, що стримують реалізацію молодіжних цільових програм в Україні, можна віднести: недосконале правове регулювання, недостатня наукова обгрунтованість процесу реалізації молодіжних цільових програм; відсутність ефективної взає модії між центральними та місцевими органами виконавчої влади, а також різноманітними громадськими об'єднаннями; відсутність чітких прав та обов' язків, які лежать перед молоддю та іншими суб'єктами реалізації цільових молодіжних програм. Вирішенню вищенаведених проблем сприятимуть вчасно створені організаційні, соціально-економічні, політико-правові умови щодо соціального становлення та розвитку молоді.

\section{Література:}

1. Державна молодіжна політика: здобутки та невирішені проблеми [Електронний ресурс]. - Режим доступу: http://studopedia.com.ua/1_53125_molodizhnapolitika-nezalezhnoi-ukraini-z--roku.html
2. Державна цільова соціальна програма "Молодь України" на 2016-2020 роки [Електронний ресурс] Режим доступу: https://zakon.rada.gov.ua/ laws / show $/ 148-2016-\%$ D0\%BF

3. Державні молодіжні програми в Україні [Електронний ресурс]. - Режим доступу: http://studopedia.com.ua/1_53129_derzhavni-molodizhni-programiv-ukraini.html

4. Кульчій І.О., Лебедин Т.В. Аналіз програм розвитку державної молодіжної політики в Україні / І.О. Кульчій, Т.В. Лебедин / / Молодий вчений: наук. журн., 2015. № 6 (3) (21). - С. 120-124.

5. Мунтян В.В. Державні цільові програми як інструмент фрінансування молодіжної політики в Україні / В.В. Мунтян / / Економічний вісник Запорізької державної інженерної академії. - 2016. - Вип. 6 (2). - С. $127-131$.

6. Про Загальнодержавну програму підтримки молоді на 2004-2008 роки. Верховна Рада України; Закон від 18 січня 2005 року № 2353-IV [Електронний ресурс]. - Режим доступу: http://search.ligazakon.ua/ I doc2.nsf / link1/T031281.html

7. Про затвердження Державної цільової соціальної програми "Молодь України" на 2009-2015 роки. Кабінет Міністрів України. Постанова від 28 січня 2009 р. № 41 [Електронний ресурс]. - Режим доступу: http://zakon4.rada.gov.ua/ laws/show/41-2009$\%$ D0\%BF

References:

1. Studopediia (2019), "State youth policy: achievements and unresolved issues", available at: http: / /studopedia.com.ua/1_53125_molodizhna-politikanezalezhnoi-ukraini-z--roku.htmō (Accessed 14 March 2019).

2. The Verkhovna Rada of Ukraine (2019), "The State Target Social Program "Youth of Ukraine" for 2016-2020", available at: https://zakon.rada.gov.ua/laws/show/ 148-2016-\%D0\%BF (Accessed 11 March 2019).

3. Studopediia (2016), "State youth programs in Ukraine", available at: http://studopedia.com.ua/ 1_53129_derzhavni-molodizhni-programi-v-ukraini.html (Āccessed 15 March 2019).

4. Kul'chij, I. O. and Lebedyn, T. V. (2015), "Analysis of programs of development of state youth policy in Ukraine", Molodyj vchenyj: nauk. zhurn, vol. 6(3) (21), pp. $120-124$.

5. Muntian, V. V. (2016), "State Target Programs as an Instrument for the Financing of Youth Policy in Ukraine", Ekonomichnyj visnyk Zaporiz'koi derzhavnoi inzhenernoi akademii, vol. 6(2), pp. 127-131.

6. The Verkhovna Rada of Ukraine (2005), The Law of Ukraine "About the National program of youth support for 2004-2008", available at: http://search.ligazakon.ua/ I_doc2.nsf / link1/T031281.html (Accessed 12 March 2019).

7. Cabinet of Ministers of Ukraine (2009), Resolution "On Approval of the State Target Social Program "Youth of Ukraine" for 2009-2015", available at: http://zakon4.rada.gov.ua/laws/show /41-2009-\%D0\%BF (Accessed 11 March 2019).

Стаття надійшла до редакиії 26.03.2019 p. 